\title{
The Nature of PKK Terrorism in Turkey
}

\section{NUR BILGE CRISS}

\author{
Department of International Relations \\ Bilkent University \\ Ankara, Turkey
}

\begin{abstract}
This study is undertaken to evaluate the profile of the PKK (Kurdish Workers Party) and Kurdish political behovior separately in an attempt to distinguish the Kurdish issue from terrorism. PKK's profile has changed between 1978, when it was founded and now, depending on Turkey's internal politics as well as the changing international environment. Basically, it started out as a Marxist-Leninist separatist organization, but by 1990 switched to demanding a federation of Kurds and Turks, and simultaneously bidding for a role in an independent Kurdestan comprising southeastern Turkey and northern Iraq. $P K K$ 's only consistent policy is to have remained a Marxist-Leninist organization so far. The first part of this article addresses the roots, objectives, and methods of the PKK. The second part assesses the problem within Turkey's domestic environment, with a focus on whether PKK truly represents Turkey's Kurds. The third section tries to answer the question of who provides the logistical and financial support for PKK, thereby exploring the issue's international dimensions. The last section evaluates prospects regarding a "political solution" to the problems of the southeast, which is now being voiced in both Turkey and Western capitals.
\end{abstract}

Current history is characterized by dichotomous forces of integration and disintegration/anarchy. Turkey has not remained outside these trends. Turkish governments strive to integrate their economy into the world system by becoming a full member of the European Union (EU). Although this may not happen in the foreseeable future, 1996 is targeted for a customs union with the EU. In April 1994, the country experienced an economic crisis that the government is trying to manage through radical austerity measures. Fighting against the forces of anarchythat is, against PKK terrorism - has contributed much to the current economic instability. Though only a fraction of Turkey's Kurds are involved with terrorism, three issues appear to have internationalized Kurds in recent years-the first and second Gulf crises and the terrorist activities of PKK (the Kurdish Workers'

This study was conducted under the auspices of the Konrad Adenauer Foundation (Bonn, Germany).

Address correspondence to Dr. Nur Bilge Criss, Faculty of Economics, Administrative, and Social Sciences, Bilkent University, 06533 Bilkent, Ankara, Turkey. 
Party), conducted mainly in the southeastern region of Turkey. Often, however, this organization is perceived in the West as representing Kurdish nationalism. Further, when both the domestic and foreign media label this violent activism as "ethnic separatism" or "secessionism," they only add more confusion to a very complex affair. Much lip service is paid to the point that terrorism and the Kurdish issue are two different factors, but it is apparent that they are closely identified with each other in the minds of many people, especially those who are committed to the enhancement of human rights.

\section{PKK's Roots, Objectives, and Methods}

The Turkish Left began organizing legally as of the early 1960 s by taking advantage of the liberal 1961 constitution. The radical journal Yön symbolized a revolutionary kind of socialism that even the Turkish Labor Party did not advocate. Followers of this journal were elected as leaders of debate clubs that sprang up in the major universities, and by 1965 these clubs formed a national confederation. In 1970, the Federation of Debate Clubs was reorganized as the Revolutionary Youth Federation (Dev-Genç) under radical leadership. Out of Dev-Genç grew a number of groups such as Turkish Revolutionary Culture Hearths of the East. The only difference between these groups was that of strategy; otherwise they followed the Marxist-Leninist or Maoist line. Another group, the Turkish People's Liberation Army (TPLA), led by young men of Kurdish origin, wanted to begin revolution in the countryside. According to their strategy, if southeastern Turkey could become a liberated zone, supportive foreign countries would be invited to join the struggle. TPLA divided Turkey into several zones, leaving the east to a spontaneous Kurdish insurrection.' It was in this atmosphere of methodological debates and leftist agitation that a Kurdish student at the Ankara University's Political Science Faculty, Abdullah Öcalan, joined the Revolutionary Youth Organization. The leftist extremists did not consider the "liberation of Kurds" separately from that of the entire country. Therefore, having decided that "liberating" the Kurds was his first priority, Öcalan began to build an organization for this task.

Thus the story of the PKK dates back to the early 1970s. It emerged not in the guerrilla camps on the rugged terrain of southeast Turkey, and not in the Middle East, but in Turkey's capital city one day in 1974. In other words, as far as its original roots are concerned, the PKK came to being not in the Kurdish populated eastern parts of the country. It has, however, always been dominated by Öcalan. ${ }^{2}$

Between 1974 and 1978 Öcalan spent his time studying theories of revolutionary activity and organizing a party. In 1978, PKK was formally but clandestinely established. Its mission was to make a communist revolution by guerrilla warfare, and establish a separate Kurdish state. However, at that time PKK lacked arms as well as militants. In order to finance its activities, it turned to robbing jewelers' 
stores and getting involved in drug trafficking. Since all of the leftist terrorist organizations used the same methods, PKK went undetected by the authorities as being a distinct group.

Meanwhile, since a series of coalition governments failed to curb terrorism and to apply economic austerity measures, which were hampered by strikes and lockouts, the military leadership decided to take over. On the eve of the September 12,1980, military coup, PKK leaders left Turkey for the Syrian-controlled Bekaa valley. They might either have foreseen that a coup was in the making or have been in search of a safe haven abroad, for their activities were very limited because of an existing martial law in the eastern and southeastern provinces. At that time, the Syrians hosted all types of leftist terrorist organizations, whose militants received guerrilla warfare training in many camps.

Between 1980 and 1984, Öcalan consolidated the party structure and established himself as the undisputed leader of the organization, often by brutal methods against dissenters. According to those who managed to escape from his camp, Öcalan had his closest followers tortured and executed, after accusing them of being Turkish government agents, when he suspected any dissent. This caused splits in the PKK, and some who managed to escape from Lebanon established their own organizations in Europe and/or joined others such as TEVGER (Kurdistan Liberation Movement), a united platform composed of Kurdish movements outside PKK. ${ }^{3}$

Following the September coup, many militants of Kurdish origin who were not related to PKK but were members of a leftist splinter group, TIKKO (Türkiye Isçi, Köylü Komünist Ordusu, Turkish Workers' and Peasants' Communist Army), found common cause with PKK militants in prisons when they were sentenced to various prison terms by the state security courts. Some joined PKK camps in Syria and Lebanon once they had served their prison terms or had broken out of jail, as many were successful in doing.

As of 1984, the military arm of PKK, ERNK (Kurdistan National Liberation Front), was established, but it fell short of the desired impact because its hit-andrun missions lacked regional support. As a result, Öcalan decided to set up the ARGK (Kurdistan Popular Liberation Army), which was supposed to be the nucleus of a people's army. After that, the PKK increased hit-and-run operations in Turkish territory, with the odious result of now having killed nearly 10,000 people, the majority of whom were Kurds. The PKK's objective in murdering its own kin has been threefold. First, it demonstrates to the people that the PKK is a strong force with whom they should side and rise up in rebellion against the Turkish state. This objective may defy logic, but it is nonetheless a traditional behavior in tribal power politics. Second, it sends people the message that as long as they remain passive, PKK will consider them to be on the enemy's side and therefore punish them. Third, PKK's wrath is mainly directed against village guards whom the state arms and employs against PKK attacks. They not only murder individual guards, but massacre entire families of guards, including women, children, and babies. This method, however primitive, has long been common in blood feuds among the people of that region, though not on this scale, and only adds to "bad 
blood" between the many Kurdish tribes who are pro-Turkey and the PKK. However, this has not stopped some of the village guards from collaborating with both the state and PKK when they get involved in selling arms to the latter, or from participating in the lucrative narcotic smuggling that feeds PKK's coffers. Therefore the wisdom of arming and paying a monthly salary to some 40,000 village guards who face losing this income when terrorism subsides is now being seriously questioned. While this measure may have served the state in the short run, there are indications, such as village guard demands for salary raises and social security, that the guards would like to settle for permanent salaried positions instead of reverting to toil. It would not be in this group's best interests, then, for terrorism to be totally overcome.

By 1992, the number of PKK militants and supporters was reputed to be about 10,000. How did this happen? Among the methods used by PKK militants to recruit manpower were kidnapping young men and women or threatening to kill boys approaching the age of military service unless they joined the organization. Once boys were recruited in this manner, families naturally were inclined to lend support, at least by way of food, clothing, and shelter. And should the young man lose his life in a clash with security forces, an entire clan of such a family could be converted. Outright greed on the part of some village guards to extract as much benefit from their employment as well as from supporting PKK, sometimes for the purpose of self- or family insurance, created an impasse. In addition, heavy-handed approaches by the gendarmerie against the people whom they suspected of collaboration with PKK provoked sympathy for the organization.

The high birthrate and ensuing problems with unemployment are another reason that PKK's ranks swelled. For example, in 1993, while the annual birthrate in western Turkey was $1.9 \%$, it was $4.1 \%$ in the east. ${ }^{4}$ Moreover, the Turkish state built regular lycées but no vocational or professional schools in the region. This resulted in a number of reasonably educated but unemployed youth. This pool also became a breeding ground for PKK recruits.

The last but perhaps most important reason that by 1992 PKK had become the major problem for Turkey was the attitude of Turkish leadership. Between 1983 and 1989, Prime Minister Turgut Özal's evaluation of the PKK was that they were only a bunch of bandits. Underestimating PKK caused loss of valuable time. Resources and proper equipment and training were not provided to fight against guerrilla warfare. ${ }^{5}$ The 1983 ban on expressing oneself in Kurdish was lifted, but it remained a hollow gesture in the face of increasing terrorism. This suggests that granting cultural rights does not necessarily mean that terrorism will automatically cease, though it may be an aspect of containment.

In sum, PKK began to change the balance in regard to its own support between 1987 and 1990. As terrorist attacks forced Ankara to take a tougher stance, people of the region were forced to take a neutral position. They observed that "normal civilians" were not PKK's targets but that those who had ties with the state were. Hence neutrality (self-survival) amounted to tacit support.

In 1990, there were clear signs of change in PKK policies. Until then the PKK had only employed what it termed "armed propaganda." Now the time was 
ripe to assume a political identity along with armed struggle. Öcalan had detected Western, and especially European, distaste for the low-intensity warfare that was going on in southeastern Turkey. He decided to redirect human rights violations away from PKK toward the Turkish state. Thus began a propaganda and disinformation campaign in Europe through cultural associations of Kurdish guest workers and political/cultural associations set up by Kurdish activists in exile.

At its second National Congress in May 1990, the PKK made certain resolutions. Among these were

to establish friendship with religious movements as they are truly against the institution (system/state) . . . . To exist within a legal socialist party with our mass forces ... . To pull the Turkish popular masses and the left-wing forces into the struggle against the special warfare put into practice in Kurdistan and to propagate for the brotherhood of the two people in order to activate this. ${ }^{6}$

These policies were to be carried out simultaneously with acts of sabotage. PKK began to turn its guns increasingly toward public servants and security forces.

PKK propaganda claimed that state authorities were responsible for unsolved murders, that entire villages had been burned down, that Kurds were treated as second-class citizens and that their cultural identity was not acknowledged, that Kurds had been oppressed for centuries, and that they were not allowed to speak their own language.

Every murder in the region that might have been caused by blood feuds, honor, or plain personal vendetta was immediately attributed to the state. Struggle for regional leadership within the PKK ranks sometimes ended up in murder, which was again blamed on the state. And terrorist tactics were not above killing people who were loved and respected in the region-those who headed local Human Rights Associations, or even selected socialist party candidates as witnessed in 1994. But these murders remained unsolved, and fed conspiracy theories.

In addition, the Hizbollah faction casts another shadow of doubt on unsolved murders. A self-styled Hizbollah ("Islamic" terrorist organization) has been active in the area and appears to be the armed protector of the pro-Islamic Welfare Party. According to many observers, throughout 1993, in Diyarbakir, whenever Öcalan ordered that all businesses close down their shutters, the only businesses that did not do so were those protected by Hizbollah guards bearing Kalashnikovs. Lately, some Hizbollah militants have been arrested and charged with responsibility for a number of such unsolved murder cases.

As to entire villages being razed, there are 5,000 villages and 7,000 hamlets in the region. In many cases, hamlets comprise three to five houses sheltering 30 to 40 family members. That is why, when PKK hit these hamlets, casualties were so high. The impossibility of protecting each hamlet and even the larger villages close to the borders, given the general adverse weather conditions and rugged mountains, compelled the security forces to move people away from border areas. Also, many homes were razed so that they could not be used as shelter 
by PKK militants. Compensation for property loss is lacking and is a point of criticism. But it is also a fact that over the past years there has been a steady and voluntary migration from this area to cities elsewhere in Turkey.

When confronted with the accusation that Kurds have been discriminated against, the immediate reaction of Turks is to start naming armed forces commanders, parliamentarians, ministers, professors, and even presidents of Kurdish origin. Lately, Western diplomats qualify this reaction with the statement, "Yes, but as long as they act like a Turk-that is, conform." On the one hand, it is unimaginable for any responsible professional in any country not to conform to the laws of that country. On the other hand, Kurdish cultural identity is on the rise after having been ignored throughout the history of the Turkish Republic. The state might as well prepare to recognize ethnic cultural rights of this group, who obviously have not been assimilated like the rest of the ethnic or immigrant communities. Cultural identity appears to be the only nonthreatening aspect of ethnicity for a unitary state.

While a Kurdish identity based on nationality has not been acknowledged for reasons that will be taken up in the next section, a cultural identity has always been acknowledged tacitly, and, as of the early 1990s, officially. Moreover, accusations of discrimination do not account for the continuous and numerous intermarriages that have been taking place for centuries.

Regarding the prohibition of language use, there was an unenforceable ban on the books between 1983 and 1991, and throughout the history of the Turkish Republic, printed material in other than Turkish and Western languages was not allowed. But speech is another matter. Today, thousands of Kurdish people, the majority of them being women of the region, do not know Turkish. Accessibility to schools, lack of transportation to even neighboring communities, and the ultraconservatism of the families prohibited these women from attending school.

There is yet another dimension to the problem. Illiterate boys who serve in the military are given elementary education. In the 1960s, those of Kurdish descent frequently objected to learning to read and write in the "unbelievers" (i.e., Latin) alphabet. Not Turkish per se, but the alphabet itself was objectionable to those Kurdish youth on religious grounds. The history of Kurdish rebellions in Turkey in 1924, 1926, and 1936-1938 is colored with religious sentiment against a secular state. Whether rising against the state was truly motivated by religious fervor or whether this was used as a cover for Kurdish nationalism is still debatable. However, the strong religious sentiments of the Kurds forced PKK to change its parlance by the 1990s and further may have allied many Kurds-some claim under Öcalan's directives - to vote for the pro-Islamic Welfare Party in the 1994 local elections. Both PKK and the Welfare Party would ultimately like to transform the Turkish state. The former wants a federation of Kurds and Turks; the latter wants a totalitarian state ruled by Shari'a laws. For PKK to endorse the Welfare Party would be a marriage of convenience, not love. The Welfare Party's "promised land" appears to be a Kurdish confederation encompassing Iran's, Iraq's, Syria's, and Turkey's Kurdish populations. The common denominator would be living under an Islamic regime. ${ }^{7}$ But whose Islamic regime? The Welfare Party is quite ambiguous about drawing a line between Pan-Islam and irredentism. 
Öcalan is shrewd enough to realize that one cannot ride the fundamentalist tiger for long, especially after the experience of the Iranian Kurds. Along with all other factions, the Kurds in Iran had supported the Islamic revolution, thinking that Khomeini could be controlled. The 1980 Kurdish rebellion in Iran, because their aspirations for autonomy were not met, resulted in the execution of 10,000 Iranian Kurds. Khomeini subsequently began to call on the unity of Islam that transcends sectarian, ethnic, racial, and national loyalties in order to keep unity in Iran, where other ethnic groups outnumber Persians. ${ }^{8}$ Hence PKK may opt to gamble with a religiously oriented party in the short run, but clearly cannot expect salvation from that quarter for long. Further, in the 1994 local elections, the Welfare Party candidates were successful in winning 350 mayoral seats but were not nearly as successful in winning seats in provincial, town or city assemblies either in the region or nationwide. Therefore one is compelled to look for other reasons behind the votes that went to the Welfare Party mayors in the southeastern areas that had traditionally voted for the Social Democrats, instead of aso far unestablished-PKK order. Some people were perhaps attracted to the Welfare Party promises that in the future, living in an Islamic community as opposed to a nation-state, all Muslims would be equal. The terms of such equality, however, have not been identified to this date. The question of PKK's representativeness of Turkey's Kurds will be evaluated in the second part of this study in light of the known orders of Öcalan regarding the 1994 elections-namely, that people should boycott the elections but, if they had to vote, should spoil the votes.

Nevertheless, PKK had to flirt with religion for a number of reasons. First, by 1990 it had became obvious that the Marxist-Leninist (hence atheist) PKK was unable to draw the mass support it needed from a society in which religious sentiment was very strong. Second, ties were forming between the Iranian Islamic Republic and PKK (for reasons other than Iran's support for Kurdish terrorism per se, which will be discussed in the third part of this article). Third, Öcalan suddenly realized the importance of religion as another support mechanism. As of 1989 PKK propaganda leaflets and brochures began and ended with prayers. Islam was being lauded as a revolutionary force in itself.

Accordingly, between 1990 and 1993, PKK was the beneficiary of (1) the lack of a coherent policy on the part of the Turkish state, whose leadership consistently underestimated the issue; (2) the power vacuum in northern Iraq following the Gulf War of 1990-1991; (3) the escalating risk environment around Turkey's borders; and (4) overt and covert propaganda against Turkey, playing on the human rights aspect. This is not to deny that there have been violations of human rights, but to point out that cases of individual abuse were turned into gross generalizations of violations of human rights by the PKK propaganda machine.

Propaganda coupled with Western sensitivities on human rights culminated in a crisis between Germany and Turkey in 1992. Following TV camera shots depicting an armored vehicle carrier that was pulling the dead body of a PKK militant, tied to it by a rope, the German government enforced an arms embargo against Turkey. The German government claimed that 
the armored vehicle carriers were given to Turkey on the condition that they would not be used outside NATO purposes. . . . A message from Turkish Minister of Foreign Affairs, Hikmet Çetin, reiterated the fact that Germany and Turkey were both party to the NATO Strategic Concept of 1991, the Washington Treaty and the London Declaration to safeguard the freedom and security of all member states.?

While the new NATO Strategic Concept included combatting terrorism, popular sentiment against Turkey ran high in Germany, and while the Turkish Foreign Minister couched the incident in refined diplomatic language, Turkish security forces on the spot in the southeast region had to survive. The dead body of the PKK terrorist was tugged in that manner because the PKK militants were known to set booby traps under the bodies of their dead such that when security forces moved the bodies, they were blown up. But emotions fed by local PKK propaganda in Germany were running high enough to compel the German government to impose an arms embargo on Turkey. PKK was becoming a political force with which to be reckoned. By its methods, whether violent or political, PKK forced the Turkish state not only to adopt a policy vis-à-vis terrorism but also to further its democratization process. The current debate is on methodology, not principle.

\section{Turkey's Domestic Environment}

Although Turks were the last of the Ottoman communities to come to grips with nationalism, that very Ottoman heritage and perspective did not allow for racial/ ethnic discernment except on the basis of religion. Therefore the philosophy behind recognizing only particular minorities in the Turkish Republic-namely, Jews, Greeks, Armenians, and other minor Christian sects in the Treaty of Lausanne (1923) - was based on protecting religious rights. Otherwise, there was not and has not been any need to protect Muslims' religious rights. Accordingly, the term minority has a very special connotation for the Turks, which is exclusive of all Muslim Turkish citizens. The British delegation at Lausanne were not able convince the Turks to recognize Muslim minorities because it was simply not an issue.

During the euphoria of nation building, however, "Turkishness" may have been overplayed to the extent that geographical names were changed to Turkish, and giving children any names that were not "Turkish" meant a long battle with the bureaucracy. Yet there is no objection to names such as Isa (Jesus), Ismail (Ishmael), Ilyas (Elias), and Danyal (Daniel). But had Turkish society not been conscious of this paradox, the majority of the people could not have accepted the late President Özal's official recognition of Kurdish identity. Language, identity, and folklore are acceptable notions in Turkey, whereas the idea of an "ethnic minority" falls on deaf ears as far as the Muslim population is concerned.

Studies on ethnic groups in Turkey found 47 such groups. Four Kurdish groups were identified as Sunni, Alawi, and Yezidi, in addition to Alawi and Sunni Zazas, whose Kurdishness, based on language, is refuted by a Kurdish linguist. This is based on the fact that Zaza and Gurmanj (spoken by the majority 
of Kurds in Turkey) are mutually unintelligible. ${ }^{10}$ However, "the question must remain as to how the existence of these groups can be equitably recognized within a national commonwealth." 1 The Ottoman Empire was a commonwealth of proto-nations that disintegrated into 12 nation-states. The Republic of Turkey is inevitably a mirror of the empire, accommodating 47 known group identities. The republic, too, from an ethnic viewpoint is a commonwealth. On this basis alone, the state would not opt for a federation on ethnic grounds and do justice to all other ethnic identities. Demographic distribution is another factor that would render such an eventuality unfeasible.

According to one writer, the recent success of the Welfare Party in the 1994 local elections "will inevitably catalyze a new social contract in this country whose ethnic, religious, and sectarian divisions are becoming more apparent as time goes on. The social contract will have to of necessity be based on democratic ideals in order for all to have their breathing space." 12

It may have taken PKK terrorism and the Welfare Party to introduce to the Turkish political milieu the idea that economic liberalism alone does not make a country liberal. Intellectual liberalism, which would encompass recognition of cultural plurality and free expression of identities, would almost ensure voluntary assimilation to the dominant culture, as happened in the United States. (Yet the official language in the United States remains English, and in no state is the primary medium of public education other than English. Spanish remains an optional second-language course even in those states with a majority of Spanish-speaking people. A similar step might address the language issue for the Kurdish population.)

What else could the new social contract cover? There seems to be no alternative but to suggest that the best solution lies in furthering democratization and political liberalism, which would culminate in providing autonomy to local and regional administrations. Such autonomy would comprise freedom to raise funds for municipal ventures and to impose local taxes for regional economic development purposes. However, a viable supervision mechanism is necessary over local administrations so that elected leaders do not turn out to be regional lords. The issue at stake seems to be economic underdevelopment, not ethnic separatism. The latter appears not to be the will of the majority of either Kurds or Turks. Presenting the issue in these terms, however, should not draw attention away from a "Kurdish issue" that desperately awaits a solution as a domestic problem.

But who represents the Kurds as a reliable party acceptable to both Kurds and the state? PKK claims to represent the Kurds of Turkey. A PIAR-Gallup poll in 1992 found out that $29 \%$ of the region's population and $28 \%$ of the people nationwide agreed. ${ }^{13}$ In a book of interviews, none of the 23 Kurdish intellectuals and leaders endorsed PKK's representation, however. ${ }^{14}$ Another fact that speaks for itself about PKK's alleged representation is that in the 1991 general elections the People's Labor Party (HEP-Halkın Emek Partisi), founded in 1990 by a group of Kurds, ran on the Social Democratic Party (SHP-Sosyal Demokrat Halkçı Parti) ticket. HEP's decision was plausibly based on the fact that in the previous 1989 local elections mayoral candidates who were known to be proPKK had only attracted $7 \%$ of total votes. In addition, the Turkish Constitution 
forbids political parties to be established on the basis of class, religion, and ethnic groups. That HEP was founded following the resolution of PKK's Second National Congress "to exist within a legal socialist party with our mass forces" was hardly a coincidence. However, the majority of the approximately 12 million Turkish Kurds do not live in the region. About 5 million live in east and southeast Turkey. And because those living outside the region voted, most Kurds must have been represented by other political parties.

HEP was closed by a Constitutional Court decision on July 14, 1993, because its radical members immediately began to exhibit pro-PKK behavior, wearing PKK colors and adopting PKK slogans in the Turkish parliament. Although politicians whose party is closed by the Constitutional Court are barred from politics for 5 years, deputies can circumvent such a prospect. Most resign from their party before it is closed and are free to establish a new party once the former is dissolved. Therefore as soon as HEP was closed, the same deputies formed the Democratic Party (DEP). But they continued to behave in a less than sophisticated manner. For instance, two of them visited the U.S. State Department on official Turkish passports to complain to junior American bureaucrats about the Turkish government.

The state prosecutor's case accused HEP deputies, among other offenses, of racism because of their public references to a Turkish nation and a Kurdish nation, which had the potential of provoking unmitigated differences into a civil war. ${ }^{15}$ As a group identity, Kurdishness is undeniable. But ethnicity, when not linked to race, is a matter of culture. Otherwise, it would be impossible to explain why Circassians, including émigrés from the Caucasus following the 1877-1878 war between the Ottomans and the Russians, having settled in the east and southeast region, call themselves Kurds today. A prime example is the deputy Chairman of DEP, Remzi Kartal. He is culturally a Kurd, but a descendant of a family that migrated from the Caucasus, not "Kurdish" at the time. Therefore it is ironic when a representative of cultural ethnicity demands a "binational" state for Turkey. This idea has at least one academic supporter known to the author. In Turkey: A Modern History, Erik J. Zürcher states,

Courageous steps are needed in the direction not of a Kurdish national state, which would have the greatest repercussions for the millions of Kurds living in Turkey's big cities, but for real bi-nationalism. Turkey will have to become a bi-national state, with Kurdish as its second language in the media, in education and in administration. ${ }^{16}$

Turkey cannot afford the luxury of experimenting with a binational state, even under the most liberal circumstances, simply because of its geostrategic and geopolitical status and, perhaps more important, because this is not the preference of the nation. While introducing such concepts may feed academic revisionism, it definitely does not correspond to Turkey's realities psychologically, politically, or strategically.

In March 1994, the immunities of five extremist DEP deputies were lifted so 
that the courts might look into criminal acts, including collaboration with PKK. One may be driven to think that the sole motive of these deputies was to force the state to take radical steps. These steps, in turn, would promote international pressure on Turkey. Otherwise, one cannot account for DEP Chairman Hatip Dicle's public comment concerning the February 1994 bombing murder of five unarmed cadets at a train station in an Istanbul suburb, that in a state of war such incidents were normal. This statement came at a time when the authorities were looking into alleged organic ties between DEP and PKK.

One DEP deputy is being investigated on charges of laundering illegal PKK money, others on charges of propagating change of the regime. Yet there are sufficient moderate members of the party that faces closure who are working to re-form as another political party. The new party is to have a broader base by including Turks, and reportedly will adhere to leftist philosophy.

An incident that raised questions about PKK's real strength was the 1994 local elections. DEP had withdrawn from the elections because several of their candidates had been assassinated, having fallen victim to unsolved murders. At the same time, PKK had threatened all other political parties and the electorate with reprisals if they ran for office or cast votes. If the people did go to the ballot boxes, they were supposed to cast blank votes.

According to unofficial results, the turnout by voters in Diyarbakır, where the PKK is believed to be strong, was $79.86 \%$, with the percentage of spoiled votes standing only at $7.8 \%$. In Hakkari, $89.40 \%$ of the voters turned out, with spoiled votes at only $7.8 \%$. In Sirnak the turnout was $74.54 \%$ and spoiled votes only $8.3 \% .^{17}$

These results signaled two facts. First, PKK's instructions were not heeded, and people went to the ballot box. Second, by this behavior, the people of the region showed the state that they should no longer be suspected of being potential or actual PKK supporters. The final election results support this contention. ${ }^{18}$ In 1989 , without any orders from PKK to spoil votes, invalid votes were $5 \%$, the rate of voter participation in eastern and southeastern Turkey being near $80 \%$. In 1994, following orders from PKK to boycott the elections or cast invalid votes, final election results were as follows: 3.8 million people (Kurds and non-Kurds) voted, indicating $88 \%$ participation. Invalid votes were $15 \%$ of those cast. If $5 \%$ is taken as a margin of error based on 1989 figures, then the actual votes spoiled were $10 \%$. This implied that fewer than 300,000 people of the more than 2 million Kurds who voted obeyed PKK's orders. Figures do not show the PKK and its regional support to be representative of Kurds or non-Kurds living in east and southeast Turkey. However, in April the pro-PKK monthly journal Sterka Rizgari announced the number of voters in 20 "Kurdish" provinces to be $4,533,471$, valid votes cast as $3,508,510$, and invalid votes cast as $3,368,143$. The total votes, then, far exceeded the number of registered voters cited by the same source by some 2,343,182 unaccounted persons.

Further, the pro-Islamic Welfare Party votes for local administrators have 
increased from $10 \%$ to $19 \%$ nationwide on a single-tier election system including the Kurdish votes attracted. Consequently Welfare Party mayoral candidates won by $18 \%$ to $21 \%$ of the votes. This victory made a sham of the PKK's representativeness and showed that the media had greatly exaggerated it. This pattern clearly leaves the initiative to the Turkish state to induce major acceptable reforms in the east and southeastern region of Turkey, and to no one else, for there do not seem to be any other viable representatives yet.

Another dimension of the Kurdish issue is the economy. There is a proliferation of literature on Kurdish history, language, and literature, and on the plight of Kurds in southeastern Turkey, which is due to underdevelopment, tribalism, and near-feudalism. Until recently, among the many ambiguous demands of Öcalan, one thing was clear. Even he, who does not represent Turkish Kurds, announced more than once that the PKK does not demand separation and that Kurds will need Turkey for a long time to come, economically speaking, but that he would welcome a federation of Kurds and Turks.

Though a federative reorganization seems out of the question for Turkey, which has committed itself to a unitary state for historical, political, and social reasons, the heart of the matter, even for Kurdish extremists, lies in the economy. However, several months later, once the PKK coffers were full of money obtained through extortion and drug trafficking, the organization was ready to fight for an independent Kurdestan comprising southeastern Turkey and northern Iraq. The changing risk environment of Turkey and the power vacuum in Iraq had much to do with PKK's simultaneous objectives.

PKK caused a temporary halt to investments in the southeast when Turkish intelligence publicized that terrorists were extorting money from bidders of government contracts and from public workers. The world's third largest dam and irrigation system, called the Southeastern Anatolia Development Project (Güneydoğu Anadolu Projesi, GAP) was put into motion by the State Planning Agency in 1965. Consequently development projects in the area were not adopted for fear of ethnic separatism or to appease the Kurdish population, but were inherent in the overall development plans for the country. By 1996, water from the Atatürk Dam (of GAP) will be used to irrigate 150,000 hectares of land. Subsequently, 22 dams and 17 hydroelectric plants will be completed at a cost of U.S. $\$ 32$ billion to the Turkish economy. ${ }^{19}$ Currently under construction, the six-lane highways between Adana, Gaziantep, Sanlıurfa, and Diyarbakır will provide job opportunities for the local population, about 50,000 of whom are still nomads.

Although Turkey is already agriculturally self-sufficient, the decision to invest in the southeast to further increase agricultural production is based on the determination to bridge the gap between the development levels of western and eastern Turkey. Economists agree that this policy alone contributes to the high inflation rate in all of Turkey. The state, however, is committed to complete the project, whatever the short-term costs will be. But without a rational land reform program to accompany the development project, a major aspect of the Kurdish issue - that is, the problem of unpropertied peasants, will not be addressed.

Turkey's development plans and activities have also created problems for its 
foreign policy, in that the waters of the Tigris and Euphrates rivers became a source of contention for Syria and Iraq. Whereas Turkey attempted to resolve this issue by negotiation and agreement with Syria, the latter chose to support PKK militancy against Turkey from its territory. It is noteworthy that the escalation of PKK attacks corresponded to a time when the Birecik Dam on the Euphrates was about to be completed.

Terrorism has succeeded in adversely affecting both public and private enterprise investments in the region. One hundred and sixteen industrial plants that belong to the private sector await completion. But the sector is reluctant to proceed with the projects. The reason was put forth by Ömer Dinçkök, Chairman of the Industrial Council, Turkish Chambers of Commerce and Stock Market: "One has to become partners with PKK in order to invest in the Southeast."20

Dinçkök's statement was based on the fact that PKK routinely extorts money from people who start new businesses and benefits from bids on government contracts. Moreover, in order to finance the purchase of more sophisticated weaponry such as Stinger rockets (a number of which were discovered in mountain depots raided by the security forces in the spring of 1994), the PKK has begun to "tax" rich businessmen of Kurdish origin nationwide. Other professionals, doctors, contractors, builders, farmers, and teachers reportedly are not immune to extortion either. ${ }^{21}$

Although the largest portion of PKK's income is derived from drug smuggling, its annual budget is estimated to be TL 863 billion (U.S. $\$ 86$ million). This includes income from extortion in both Turkey and abroad, especially from Kurdish and Turkish workers, most of whom reside in Germany.

The British National Service of Criminal Intelligence (NSIC) reported that in 1993 PKK extorted 2.5 million pounds sterling from immigrants and businesses. According to the same source, PKK obtained 56 million DM from drug smuggling in Europe in $1993 . .^{22}$ In addition, only those businessmen of whom PKK approves entered bids for government contracts in the southeast, in return for a "commission" to the organization. Likewise, temporary workers in the southeast who were paid a monthly net salary of TL 12 million (U.S. $\$ 1,000$ ) were forced to give up TL 8 million (U.S. \$700) of this sum to the PKK. ${ }^{23}$

In this manner, the Turkish government ironically ended up subsidizing the terrorist organization. Therefore all investments to the area have now been stopped. The government has a two-pronged approach to the problem. One is to use military means to destroy PKK, and the other is to encourage the people to resist PKK. In the long run, it is the people who bear the consequences of lack of public services rendered. Lately, even the pro-PKK daily Özgür Gündem complained that there was only one pediatrician available for 20,000 children in the Batman region, but it failed to mention that the PKK was specifically murdering all types of public servants, including doctors, nurses, and school teachers. ${ }^{24}$

In July 1993, the Turkish Prime Minister, Tansu Çiller, promised an emergency financial aid package to the southeast. In view of subsequent developments, it appears impossible to carry out this promise, at least until terrorist activity subsides. 
Banking is yet another sector that is diminishing in the region. Since 1991, 60 bank branches have been closed, the majority of which were private banks. Banks that remain in the region closely scrutinize loans, and insurance companies charge exorbitant prices for transport and property coverages. Discrimination, which used to be nonexistent, is being forced by the PKK. Although only $4.2 \%$ of bank deposits come from the local population, people can make use of only $2.7 \%$ of the total credit available for agriculture and animal husbandry, since terrorists have been murdering entire families and destroying their animals and fields. ${ }^{25}$ And this violence is directed against their own kin simply because members of these families are village guards whom the PKK regards as collaborators of the state. The result is that the PKK condemns to abject poverty and misery the very people on whose behalf it claims to be fighting, and also turns its weapons against them.

By the end of October 1993, 700 schools in Diyarbakır were closed down, either because PKK murdered the teachers or because school buildings were burned down. Overall, 3,600 schools have been closed in the region. These schools accommodated nearly 100,000 children. ${ }^{26}$

The public sector, furthermore, had to absorb loss of income from electric, telephone, or water bills in many areas because PKK intimidated the people into not paying these bills. In certain provinces PKK banned purchase of alcoholic beverages and cigarettes, not on moral grounds, but because these products are under state monopoly. One objective seemed to be to deprive the state of income. But also the purpose was to create a psychological atmosphere in which the people would come to accept PKK as the sole representative (by force or voluntarily) of Kurdish interests.

How did PKK become a major challenge to the state by applying its own version of martial law tactics within the boundaries of Turkey? How did it become strong enough to enforce a ban on the publication of newspapers, threaten local political party officials so that they had to close down their offices, and ask all civil servants to leave the region?

In part, the PKK felt financially strong enough to act alone to achieve its ultimate goal, namely, to be recognized as the only party representative of the Kurds. But another reason may be found in the new regional power imbalance. This brings us to the issue's international dimensions, for it involves direct or indirect foreign support of PKK terrorism.

\section{International Dimensions of Terrorism}

Kurdish separatism in the Middle East was internationalized at the time of the first and second Gulf crises. Iran, Iraq, and Turkey, respectively, have been facing similar ramifications of Kurdish problems within their borders. Yet it is very premature to speak of Pan-Kurdism as long as Turkish Kurds express themselves in the Latin alphabet, Iranian Kurds in the Persian script, and Iraqi and Syrian Kurds in the Arabic script. Culturally, most Kurds have been largely assimilated into the dominant national culture of the countries where they live. Moreover, the 
structure of their respective localized societies is based on clan or tribal identity, which is very often characterized by hostility between clans or tribes. Therefore it is difficult even to structurally define the nature of Kurdish nationalism.

Although the Kurdish Democratic Party of Iran and the Kurdish Sunni Muslim Organization believe in armed struggle against the Iranian state, the Pasdaran (Revolutionary Guards) suppressed these Kurdish guerrillas. Iran's Kurdish policy during the Iran-Iraq war however, brought much strain on Turkish-Iranian relations because Iran had collaborated with and equipped Iraqi Kurds in order to tie down a major portion of the Iraqi army. But since PKK attacked Turkish villages from northern Iraq during the Iran-Iraq war, the Turkish Air Force raided PKK camps in northern Iraq in 1986-1987, with the approval of the Iraqi government. This did not please Iran because it was not in a position to discriminate between PKK and Iraqi Kurdish guerrillas, or so it claimed.

The following year, when war approached Iraq's oil-rich Kirkuk area, Turkey began to transport troops to its southern border. Iran promptly declared that if Iran took Kirkuk, it would not encourage the creation of a Kurdish state in northern Iraq. The contingency measures taken, however, were an indication of Turkey's sensitivity on the issue. Even an autonomous Kurdish region set up under Iran's sphere of influence would be intolerable to Turkey.

The second Gulf crisis resulted in the creation of a semiautonomous Kurdestan in northern Iraq. Turkish foreign policy with regard to this problem is paradoxical: Although Turkey accommodates forces of the Operation Provide Comfort on its soil to deter Saddam Hussein from further retaliation against Iraqi Kurds, it also believes in maintaining Iraq's territorial integrity. An independent Kurdish state carved out of Iraq is not in Turkey's national interest because it would be a threat to the regional balance of power. Such a land-locked Kurdish state would be economically dependent upon Turkey, and Iran would not tolerate a Kurdish state under Turkish influence. The same premise held true for Turkey, for it would not tolerate a Kurdish state under Iran's influence either. Both countries' behavior during the Iran-Iraq war points to this factor. Moreover, an Iraniansupported Hizbollah faction already regularly clashes with the Iraqi Kurdish forces of Talabani and Barzani (Patriotic Union of Kurdestan, PUK, and the Kurdish Democratic Party, KDP, respectively), forces as well as with PKK located in Iraq.

During the past 2 years, Turkey has been exposed to PKK attacks from Iranian soil. Only recently, Iran has agreed to cooperate and collaborate with Turkey to identify and eliminate PKK camps on its territory. ${ }^{27}$ For 2 years Iran may not have had any qualms about PKK's existence on its territory because it did not fear that PKK would serve as a model for Iranian Kurds. Iran deals with rebellion by outright execution. There are possibly two major reasons for its change of behavior. One is that Iran may feel more secure because of the change in Azerbaijani leadership from the ultranationalist and irredentist Ebulfez Elçibey, whom Turkey used to support (though not for his irredentist policies), to a nonirredentist Haidar Aliev. Second, Iran must have reconsidered the implications of Kurdish separatism in terms of the regional balance of power. 
Another example of how the Kurdish issue is manipulated by the regional states to suit their interests is the case of Armenia. A peculiar development in the Caucasus resulted in accommodating PKK camps in Armenia. A tiny "Lacin Kurdish Republic" was declared in Armenian-held Nagorno-Karabagh, and Kurdish villages on the border between Armenia and Turkey came to serve as bases from which PKK infiltrated Turkey. ${ }^{28}$ Although the current Armenian leadership may be sincere in working toward good relations with Turkey, it may not be able to control the extremists in its system at all times. This lack of control, coupled with the fact that a substantial number of PKK terrorists who are killed by Turkish security turn out to be Syrian citizens of Armenian origin, is not conducive to confidence building.

It may well be remembered that when, for tactical reasons, the Armenian terrorist organization ASALA, based in Lebanon, stopped assassinating Turkish diplomats, PKK terrorism began. This is curious, at least as far as timing is concerned. Considering that there is always a certain degree of solidarity between international terrorist organizations, the Armenian involvement in PKK terrorism, whether it comes from Armenia proper or from the diaspora Armenians, remains a problem for Turkish foreign policy as well as for Turkish security.

As of November 1993, Yerevan formally declared that it was ready to collaborate with Turkey against the PKK. Since there is dire need for concrete confidence-building measures between Turkey and Armenia, Yerevan's gesture is a welcome development.

Syria is yet another neighbor that has opted to support PKK, among other international revolutionary factions. There was nothing unusual about this as long as Syria served Soviet interests in the region. However, after the demise of the Soviet Union, Syrian leadership not only continued to accommodate PKK's leader in Damascus but also stepped up its involvement with PKK.

The Southeastern Anatolia Development Project (GAP) and subsequently the waters of the Euphrates and Tigris rivers became an issue of power politics inadvertently, at least on Turkey's part, between Turkey, Syria, and Iraq. Turkey, since 1987, has been trying to reassure its neighbors about the release of the downstream water. Even apart from this issue, water resources in the Middle East are becoming scarcer. By the early 1990s Hafez Assad therefore chose to force Turkey into releasing more water (from 500 to $700 \mathrm{~m}^{3} / \mathrm{s}$ ) by increasing his support for PKK. If Turkey released $700 \mathrm{~m}^{3} / \mathrm{s}$, it would only be able to use $30 \%$ of the Euphrates, although $88 \%$ of the water sources that feed the river are in Turkish territory. In addition, among the recent declarations of PKK's Öcalan was his objection to the building of the Birecik Dam on the Euphrates River. This is again indicative of the general symptom in the Middle East of using the Kurds for one's own ends.

Syria has incessantly assured Turkey that it is not supporting PKK. But in light of Turkey's ongoing development projects as of 1987, Syria escalated its involvement with PKK and at the same time refused to cooperate on the management of water flow, despite a number of protocols signed for that purpose. In the early 1990s, a Turkish delegation to Syria reportedly delivered an implied threat. 
If Syria continued to house PKK camps and its leader, if it would not sever its connections to PKK's income from drug smuggling through Syria, then Turkey would be compelled to redirect the water to channels (the construction of which is to be completed) and carry it to the Ceyhan River, which flows into the Mediterranean. From there, it would be loaded onto tankers to be sold to friendly countries in the Middle East. Ankara may not perceive itself as bound by the 1987 agreement on security and cooperation with Syria as long as the latter does not honor that agreement. A tripartite agreement could not be worked out either, because Syria and Iraq insisted on sharing the waters downstream from Turkey on unilateral declarations of need.

International law is not adequate in providing guidance on the non-navigational uses of international watercourses. Some trends are emerging, such as equitable and reasonable utilization and participation, and a general obligation to cooperate "on the basis of sovereign equality, territorial integrity and mutual benefit in order to attain optimal utilization and adequate protection of an international watercourse." ${ }^{29}$ But it is necessary for the states involved to cooperate and plan for a rational management of transboundary watercourses. In the Middle Eastern context, this becomes difficult because the water issue is utilized in power politics, and so far this behavior has been conducive to conflict even though interdependence should actually serve as a means to contribute to peace and stability in the region. ${ }^{30}$

Europe is only beginning to realize the predicament of Kurds and Turks alike. On November 4, 1993, PKK militants attacked Turkish Airline offices and Turkish banks, embassies, cafes, and businesses with Molotov cocktails in England, Switzerland, Denmark, Austria, Norway, France, and Germany. These attacks resulted in one death and 16 wounded Turks. Apart from carrying terrorism abroad, material damage to the establishment is usually compensated for by the host country, a practice that brings an additional burden on these countries. The German government has begun to move against well-known PKK agencies for the first time in the history of PKK activism in Germany. By 1994, PKK had been declared illegal both in France and in Germany, but not in the other European countries.

It is too early to expect other European countries to follow suit for a multitude of reasons. First, the number of Turkish guest workers and émigrés is not as high elsewhere in Europe as in Germany. Second, many of the émigrés into Europe who are of Turkish citizenry but not of Turkish ethnic background asked for political asylum in the past for purely hidden economic reasons. Subsequently, it was critical that they keep up the farce about exaggerated human rights abuses in Turkey. This is one reason that Europeans have difficulty in distinguishing between true and false when it comes to human rights in Turkey, barring real cases of abuse.

In sum, the problem is formidable, but the message for a resolution is clear: The problem can only be solved within Turkey through the Turkish parliament. The political will exists. The debate, however, is whether terrorist activities should be stamped out or at least minimized before a reform package can be applied, or whether the struggles against terrorism and for reform should be conducted si- 
multaneously. The current government has opted for the former. Given the effects of the aforementioned subversive acts on economic activity in the region, the government was hardly left with a choice in defining its priority. However, the southeastern question remains to be solved. The fashionable approach nowadays, both in the liberal circles in Turkey and abroad, is to suggest a "political solution," however ill-defined by the former and deliberately not defined by the latter parties. The latter posture is perceived in Turkey as stemming from Western avoidance of being impolitic and/or from not really being able to define an acceptable solution to the dilemma without trespassing on Turkish sovereignty. The issue lies in choosing between the survival of the Turkish Republic as a nation-state or not. Turkey opts for the former, but needs to manage the Kurdish issue in order to prevent anarchy and to contain those parties in the West that use the issue as an argument against Turkey's integration with the West.

\section{A Political Solution?}

A political resolution to the "Kurdish problem" concomitant with a military solution to terrorism was being voiced both in Turkey and abroad by the end of 1993 . The wording of the Assistant Secretary of the U.S. State Department, Stephan Oxman, by March 1994 was indicative of his government's official outlook.

Question (Anatolian TV): After you left the press conference, one of our colleagues asked what you might have meant by a "political solution" to the Kurdish problem. Undersecretary Sanberk suggested that question should be directed to you.

Oxman: Let me just say that nothing that I have said about that is new: it's the same position 1 expressed when I was here in December, but let me just amplify that. Turkey, first of all I want to stress, is a very valued ally of the United States and we want a strong Turkey. We support the Turkish government in its fight against PKK terrorism. We also believe that a lasting solution to the problems in the Southeast cannot be achieved through purely military means. We believe that non-military civil and social solutions must be pursued at the same time consistent with Turkey's territorial integrity, consistent with Turkey's constitution, consistent with Turkey's tradition as a pluralistic, multiparty democracy. We do not advocate any particular civil or political solution or any particular means to those solutions. Those are for Turkey to decide. But we do believe that the Turkish government must continue to pursue non-military solutions in order to bring an end to the conflict. ${ }^{31}$

The only nonmilitary solutions to this conflict seem to be nationwide reforms, one being in the form of efficient local administration, ${ }^{32}$ a change in the electoral system from a single-tier to a double-tier system, and the containment of terrorist attacks in order to be free to build up the region's infrastructure. Land reform and 
planned rational resettlement may reduce the hold of tribal leaders over the populace in the region who are pressured to vote for candidates from a particular feudal lineage. Such representatives, in turn, enhance their own interests as opposed to those whom they represent. Clearly, the so-called "Kurdish question" (while the majority of the approximately 12 million Kurds live outside the region, leaving about 5 million Kurds within the region) is related to regional problems of underdevelopment, not only economically but also in terms of the region's sociopolitical structure. The discrepancy in the current structure is not between Turks and Kurds, but between Kurdish tribal leadership and Kurdish peasantry. However, the Kurdish issue does not end within the bounds of a certain region. Given the demographic distribution, it is a nationwide challenge. But it is a positive challenge in that it directs the Turkish state to reform conceptually, structurally, and economically.

To seek a political solution in a "twilight zone" such as this one, the Helsinki Citizens' Assembly held a meeting on February 15, 1993, in Istanbul. It was in this meeting that political solutions to the southeastern problem were first verbalized by the foreign guests and various Turkish civil associations. No one among the many liberals, politicians, socialists, and Kurdish intellectuals was coherent enough to define a political solution, and the assembly could not reach a consensus on this issue.

For Hatip Dicle, chairman of DEP, a political solution meant an official dialogue with PKK. Liberally oriented business leaders suggested a dialogue between state authorities and local Kurdish leaders, without identifying them. The conservative chairman of the Turkish Association of Chambers of Commerce and Stock Markets, Yalım Erez, stated that the concept of political solution was foreign-inspired. He supported a military solution first, to be followed by reconstruction and investment in the region. ${ }^{33}$ Although there was no consensus about the myriad of suggestions, some patterns have emerged to enable a realistic assessment of the situation. First, Turkey rejects the idea of federation and regards such suggestions as trespassing on its sovereign rights. A federation would also mean succumbing to PKK. Second, PKK or its self-styled representatives will not be considered a party for dialogue. Third, the best that can be expected from demands for education in Kurdish is perhaps the introduction of Kurdish as a second language in school districts where Kurds are in the majority. Otherwise regionalism and language teaching may become a barrier to social and professional mobility, which will imply automatic discrimination. Last but not least important are increasing demands to enhance democratic rights nationwide, strengthen local and regional administrations, and lift the ban on naming places and individuals in Kurdish.

Turkey's struggle against terrorism pales compared to the anarchy being witnessed elsewhere in the world where "war itself becomes continuous with crime, as armed bands of stateless marauders clash with the private security forces of the elites." ${ }^{34}$ Such deterioration of the political and social fabric does not seem plausible in the Turkish context. With a strong state-building tradition, Turkey enjoys viable institutions such as the military, the civilian bureaucracy, major universi- 
ties, a conscientious intellectual stratum, and civil associations to keep the nationstate intact. At present, the Turkish military appears to have inflicted serious damage on PKK in northern Iraq and will be setting up watch points in strategic locations to prevent infiltration and PKK's further recruitment efforts. ${ }^{35}$ These are further security points north of the 36th parallel, which is already a security zone but is not conducive to containing PKK because it was not set up for that purpose. Iraqi Kurdish leaders probably will not object to such a temporary arrangement. They would not prefer to share power with PKK, which has proved to be a constant embarrassment to them as Turkey has poured humanitarian aid into the Iraqi Kurds.

Consequently there is not a monolithic Kurdism in the Middle East any more than communism was or Islam is monolithic. The larger picture calls for an appreciation by all policy makers that regional power balances only reinforce a greater balance of powers.

\section{Notes}

1. Nur Bilge Criss, "Mercenaries of Ideology: Turkey's Terrorism War," in Terrorism and Politics, ed. Barry Rubin (New York: St. Martin's Press, 1991), pp. 123-50.

2. Ismet Imset, The PKK (Ankara: Turkish Daily News Publications:1), p. 9.

3. Ibid., p. 406.

4. "Research on Population and Health: 1993" (Hacettepe Üniversitesi, Nüfus Etüdleri Enstitüsü), Cumhuriyet-Bilim Teknik, Apr. 23, 1994.

5. Nevzat Bölügiray, Separatist Terror During the Özal Era (1983-1991) (Ankara: Tekin Yayinevi, 1992).

6. Imset, The $P K K$, p. 228.

7. Kurthan Fişek, "The Welfare Party Should Clarify its Kurdish Policy," Hürriyet, Mar. 31, 1994.

8. Nur Bilge Criss, "Arduous Diplomacy: Turkish-Iranian Relations in the Aftermath of the Islamic Revolution," International Journal of Turkish Studies, 1994.

9. Courtney Lukitsch-Öymen, "The PKK Problem: A Continuing Source of Tension Between Turkey and Germany," unpublished paper, June 1993, Bilkent University, Department of International Relations.

10. Mehrdad Izady, "A Kurdish Lingua Franca?" Kurdish Times 2 (Summer 1988): 13-24.

11. Ethnic Groups in the Republic of Turkey, ed. Peter Alford Andrews (Wiesbaden: Ludwig Reichert, 1989), p. 42.

12. Semih Idiz, "What the Welfare Party Victory Tells Us," Turkish Daily News, Mar. 30, 1994.

13. Bölügiray, Separatist Terror, p. 33.

14. Rafet Balli, The Kurdish Dossier, 3rd ed. (Istanbul: Cem Yayinevi, 1992).

15. "Anayasa Mahkemesi Kararı," Official Gazette, Aug. 18, 1993, №. 21672.

16. Erik J. Zürcher, Turkey: A Modern History (London: I. B. Tauris, 1993), p. 321.

17. Hayri Birler, "The PKK's True Strength," Turkish Daily News, Apr. 1, 1994.

18. "Final Election Results," Turkish Daily News, Apr. 4, 1994.

19. "Southeastern Anatolia Project," Cumhuriyet, Oct. 31, 1993.

20. "Investing in the Southeast Spells Partnership with the PKK," Cumhuriyet, Oct. $26,1993$. 
21. "PKK's Income is from Extortion," Milliyet, Nov. 1, 1993.

22. "PKK's Annual Income is 863 Billion TL," Milliyet, Nov. 1, 1993.

23. Yalçin Doğan, "Investments Have Stopped in the Southeast," Milliyet, Nov. 4, 1993.

24. "One Pediatrician to 20 Thousand Children in Batman," Özgür Gündem, Nov. 5, 1993.

25. "Demise of the Banking Sector in the East," Milliyet,

26. "700 Schools Are Closed Down in Diyarbakir, Milliyet, Oct. 29, 1993.

27. Yalçın Doğan, "Turkish-Iranian Operation," Milliyet, Oct. 28, 1993.

28. "Weapons Are Facing Armenia," Milliyet, Sept. 13, 1993.

29. "The Law of the Non-Navigational Uses of International Watercourses," Draft Report of the International Law Commission on the Work of its Forty-Third Session, United Nations General Assembly, July 8, 1991.

30. "Roundtable Discussion on Transboundary Watercourses," Bilkent University, Nov. 26-27, 1990 (Report by Ali L. Karaosmanoğlu, Department of International Relations, Bilkent University, Ankara).

31. U.S.I.S. Press Release, "Assistant Secretary Stephan Oxman. Press Availability" Esenboğa Airport” Ankara, Mar. 10, 1994.

32. Selçuk Yalçındağ, "Options for Local Administration Methods: Possible Solutions," Görüs 13 (Jan. 1994): 34-37.

33. Ismail Hakkı Yilmaz and Nevzat Basım, "Political Solutions in the Twilight Zone," Nokta 50 (Dec. 5-11, 1993): 12-18.

34. Robert D. Kaplan, "The Coming Anarchy," Atlantic Monthly, Feb. 1994, pp. 44-76.

35. Burhan Eliş, "Checkpoints on the Iraqi Border," Milliyet, Apr. 29, 1994. 
Copyright of Studies in Conflict \& Terrorism is the property of Taylor \& Francis Ltd and its content may not be copied or emailed to multiple sites or posted to a listserv without the copyright holder's express written permission. However, users may print, download, or email articles for individual use. 